disease which previously resisted all attempts at control. Considerable progress in the investigation on the control of the peach moth is reported by the Division of Economic Entomology and very favourable results have been obtained with nicotinekentonite-sulphur sprays. The same Division has been responsible for work on termite control, while the work carried out on the control of weeds has been considerably extended by reorganizing the botanical and entomological phases in one section under joint control of the chiefs of the two Divisions. The Division of Animal Health Nutrition has been responsible for investigations on pleuro-pneumonia in cattle and on the treatment of internal parasites of sheep, while its fundamental investigations on the nutrition of sheep have already led to an increase of nearly 150 per cent in the yield of wool as well as to a remarkable variation in its character. Valuable contributions to viticulture and regarding the role of organic matter in plant nutrition have been made by the Soils Division, while the Food Preservation Section has obtained promising results in investiga. tions on the storage of peaches and plums from the point of view of export to Great Britain which should decrease the wastage in export. The Radio Research Board has continued its investigations; appreciable advance in the control and eradication of prickly pear by biological methods is again reported, and a programme of fisheries research has also recently been initiated.

\section{National and International Standardization}

REALIZATION of the advantages of standardization of industrial materials and requirements has led in most of the industrially developed countries to the establishment of organizations to promote such standardization, and already a high degree of standardization has been reached in many countries. A most informative account of the work of the various national authoritative bodies engaged in this work is given in "A Survey of the Present Organization of Standardization-National and International", published by the World Power Conference. In Great Britain, the British Standards Institution is the national standardizing organization and is responsible for the determination of British standard specifications. Though the Institution has a strict rule that it does not initiate standardization but waits to be approached by a recognized outside authority such as a trade association, technical institution, or Government department, it has already issued more than 560 British Standard Specifications, exclusive of some 160 specifications for aireraft materials and components issued in co-operation with the Air Ministry.

INTERNATIONAL standardizing organizations, such as the International Federation of the National Standardizing Associations (ISA) or the International Electrotechnical Commission (IEC) have also been established. ISA, for example, federates the national standardizing organizations of nineteen countries and was founded in New York in 1926 with the object of promoting co-operation, co-ordination and interchange of information. But international co-operation, in contrast to the development of standardization along national lines, has made slow progress. It was indeed the need for further development in this direction that led the International Executive Council of the World Power Conference to initiate this inquiry, and the report has been published with the hope that it may serve as a stimulus to a greater degree of co-operation in national standardization and to a closer co-ordination of the activities of international organizations engaged in standardization, to the end that duplication and overlapping may be avoided and international standardization may be more speedily effected.

\section{Scientific Basis of Birth Control}

IN Science and Society of June-September 1937 , there appears an article on "The Scientific Basis of Birth Control" by Dr. C. V. Drysdale, president of the Malthusian League. The author remarks that the true, present-day application of the Malthusian doctrine may best be understood by reference to the affairs of an ordinary married couple. "The average young man marries when his income is sufficient to support a wife and perhaps one child, and, if that income were fixed, every additional child would mean a lowering of the family standard of existence." But, in many occupations, salaries rise with age and service, and if additional children come when there has been a sufficient rise in income, no lowering of the standard need take place. "This is the population problem as it confronts almost every middle-class couple." If children arrive at a greater rate than can be allowed for by increases of salary, then such a family is "over-populated". It amounts to this, that, in general, in civilized countries, birth-control has assisted in the preservation of the amenities and standards of living. Another aspect of birth-control is, of course, its application to what is called negative eugenics, that is, the avoidance of parenthood by persons afflicted with transmissible disease or defect. Dr. Drysdale looks forward to a future in which a planned social economy shall ensure general early marriage with reasonable family limitation. But it will be necessary to arrange that the limitation does not go too far, and the question is: How ?

\section{Fauna of the U.S.S.R.}

Some years before the Great War, the Russian Academy of Sciences launched an ambitious scheme of publishing detailed monographs on all groups of animals occurring within the Russian Empire and in neighbouring countries, under the title "Faune de la Russie et de pays limitrophes". The programme of the publication was so extensive that the first few volumes which appeared were sufficient to show the virtual impossibility of continuing the work on the same scale. The idea, however, was not abandoned, and the Academy of Sciences of the U.S.S.R. has now commenced the publication of a new "Faune de l'URSS", which aims at giving a full, but concisely written, monographic treatment mainly 
of the systematics and distribution of all animals already found, or expected to occur, in the Soviet territories. Six volumes and two smaller parts, mostly dealing with insects, have already appeared, and they make a very good impression, particularly as regards the generally high scientific standard, although the paper, printing and illustrations might be improved. Unfortunately, not all the volumes are by outstanding experts in the systematics of the groups treated, and some have apparently been prepared by authors who may be excellent specialists, but not in the groups they had to monograph. All foreign zoologists will be pleased to see that each volume has a very full summary in a Western language, in which all determination keys, new descriptions and more important notes are given. Since the "Fauna". covers the whole of extra-tropical Asia and eastern Europe, its value for systematists working on the palæarctic region will be inestimable, and volumes on their respective groups will be eagerly awaited by all zoologists.

\section{The Botanical Society of Edinburgh}

The Transactions and Proceedings of the Botanical Society of Edinburgh, 32, Part 1, 1936, is a particularly interesting number, including as it does the record of the centenary meeting of this Society. The main contribution is in effect a local flora-a list of the flowering plants and ferns from Fife and Kinross by William Young. The address delivered by Prof. F. O. Bower at the centenary meeting is included. No more appropriate speaker could have been found for that interesting occasion, and his appreciation of botanical progress during the period of activity of the Society could only have been delivered by a veteran whose reminiscences still feed his botanical enthusiasm. Prof. Bower points out how plant physiology has gained since 1836 by the precision that can now be assigned to the medium in which vital functions are proceeding, through the advances in cytology and anatomy. With arresting phrase and breadth of vision, in a few pages the main movements of botanical thought during the century are brought before the reader. The last half century, it is pointed out, because it is an age of specialization, has increased the need for the services of such general societies as the Botanical Society of Edinburgh. Prof. Bower indicates how the 'herd sense' among his fellow botanists is probably responsible for the temporary ascendancy of one field of investigation, thus leading to "multiplying instances of what has been already demonstrated". He then shows himself fully aware where the 'herd' is gathering now when he ends an eloquent plea for a modern morphology, based upon developmental studies of the meristem, with the speculation that hormones may then prove the key to unlock those phenomena of symmetry that are expressed in appendages. The Botanical Society of Edinburgh began principally as a means to the formation of a herbarium for its members, and has taken a prominent part in the creation of the magnificent herbarium that is now housed at the Royal Botanic Gardens.

\section{Giorgi's System of Units}

Dr. A. E. Kenneliy recently presented a report, from the historical point of view, to the Society for the Promotion of Engineering Education, in regard to the adoption of the M.K.s. (metre-kilogram-second) system of units ("The M.K.S. System of Giorgi as adopted by the International Electrotechnical Commission (I.E.C.) in June 1935"). Dr. Kennelly has done his work well, giving a fair statement of the present position. Unfortunately, physicists and engineers are not yet agreed as to the best system of units to adopt. Many of them are in favour of following Heaviside and completely rationalizing the system of units. Others are more conservative, and think that the change, although saving much arithmetic, would scarcely be worth the labour involved in learning all the relations connecting the new and the old units. The two leading organizations are in agreement that a fourth unit is theoretically necessary to link internationally adopted electrical units with the dynamical units of the M.K.s. system. They agree that this fourth unit may preferably be 'space permeability' taken at the definite numerical value of $10^{-7}$ (unrationalized). This report of Dr. Kennelly's can do nothing but good.

\section{Prohibition and Cirrhosis of the Liver}

$A_{T}$ an address given at the recent annual meeting of the Royal Institute of Public Health at Margate, Dr. C. C. Weeks stated that, in the United States, when prohibition really was prohibiting, there was a marked decrease in the death-rate from cirrhosis of the liver and a rise as 'boot-legging' became more extensive. The liquor sold under 'boot-legging' conditions was much more alcoholic than usual, ethyl alcohol being so high as 70 per cent in much of the whisky sold. There was consequently a good deal of acute alcoholism attributed to all sorts of causes, whereas the one effective cause was that the whisky was 50 per cent stronger than usual. Since the repeal of prohibition, there has been a slight but steady increase in deaths due to alcoholism. Official figures for 1935 showed that, out of 24 States, 20 had an increase in the death-rate from cirrhosis, while only 11 showed an increase in the death-rate for alcoholism as compared with 1932. The steady drinking of a more normal alcoholic beverage was leading inevitably to more cirrhosis of the liver but to less acute alcoholism.

\section{Society of Chemical Industry: Food Group}

AT a recent meeting of the Food Group of the Society of Chemical Industry, it was decided, in view of the growing interest in food science and the diversity of the subject, to form panels within the Group. These panels will be responsible for directing the activities of the Group in connexion with their respective divisions of the science. The first two panels, of which there will be several, are now in process of formation, namely, a nutritional panel and a microbiological panel. 